\title{
Triphenylamine-based fluorescent conjugated glycopolymers: Synthesis, characterization and interactions with lectins
}

\author{
Qi Chen ${ }^{\mathrm{a}}$, Yonghua $\mathrm{Xu}^{\mathrm{b}}$, Yuguo $\mathrm{Du}^{\mathrm{b}}$, Bao-Hang Han ${ }^{\mathrm{a}, *}$ \\ ${ }^{a}$ National Center for Nanoscience and Technology, No. 11, Beiyitiao Zhongguancun, Beijing 100190, China \\ ${ }^{\mathrm{b}}$ State Key Laboratory of Environmental Chemistry and Ecotoxicology, Research Center for Eco-Environmental Sciences, Chinese Academy of Sciences, Beijing 100085, China
}

\section{A R T I C L E I N F O}

\section{Article history:}

Received 12 January 2009

Received in revised form

16 April 2009

Accepted 21 April 2009

Available online 3 May 2009

Keywords:

Carbohydrate-lectin interactions

Conjugated polymers

Fluorescence quenching

\begin{abstract}
A B S T R A C T
Two well-defined triphenylamine-based fluorescent conjugated glycopolymers were easily synthesized through Suzuki coupling polymerization of peracetylated galactopyranosyl-carrying monomer and consequent efficient deacetylation under Zemplén condition. Their structures were characterized using ${ }^{1} \mathrm{H}$ NMR, IR, and UV-vis spectroscopies. The preliminary insight into carbohydrate-lectin interactions was revealed by the titration of peanut agglutinin (PNA) to one of the final polymers, D-galactose-bearing poly(fluorene-alt-triphenylamine) copolymer (P-2), resulting in a significant fluorescence quenching of the polymer with a Stern-Volmer quenching constant of $1.56 \times 10^{5} \mathrm{M}^{-1}$. Whereas no distinct change in the fluorescent properties of P-2 was observed when concanavalin A (Con A) was employed.
\end{abstract}

(c) 2009 Elsevier Ltd. All rights reserved.

\section{Introduction}

Carbohydrate-mediated multivalent interactions play crucial roles in numerous biological processes such as cell growth, recognition and differentiation, cancer metastasis, inflammation, and bacterial and viral infections [1-3]. The affinity and specificity of these interactions depend strongly on multivalency due to the so-called glycoside cluster effect [4,5]. As multivalent model systems and artificial glycoconjugates, synthetic glycopolymers have demonstrated to be important well-defined tools for investigating carbohydrate-based biological events [6-8]. In particular, fluorescent conjugated glycopolymers that possess both fluorescent scaffolding and reporting carbohydrate ligands are attractively used in carbohydrate-protein interaction studies and biosensor applications because of their intrinsic optical properties, high sensitivities to minor stimuli, and good biocompatibilities [9-13]. A few conjugated polymers, such as polythiophene [10,11], polyfluorene [12], poly(p-phenylene-ethynylene) [13-17], poly(phenylene-vinylene) [18], and poly ( $p$-phenylene) [19], have been chosen to design this type of multivalent glycoconjugates. One approach to such a system is represented by the polymerization or copolymerization of well-defined carbohydrate-carrying monomers through classical C-C coupling reactions [10,13,15-18]. Another synthetic approach is the so-called postpolymerization functionalization, in which sugar moieties are grafted to the backbones after the formation of conjugated polymers [11,12,14,19].

\footnotetext{
* Corresponding author. Fax: +86 1082545576.

E-mail address: hanbh@nanoctr.cn (B.-H. Han).
}

With high efficiencies in both photoluminescence and electroluminescence, triphenylamine-based conjugated derivatives have gained much attention during the past decade as versatile active materials in optoelectronic devices $[20,21]$ and fluorescent sensory materials [22,23]. In this article, we reported an easy synthesis of two well-defined triphenylamine-based conjugated glycopolymers using Suzuki coupling polymerization approach. The preliminary insight into carbohydrate-lectin interactions was revealed by titration of peanut agglutinin (PNA) to D-galactose-bearing poly(fluorene-alt-triphenylamine) copolymer resulting in a significant fluorescence quenching of the polymer with a Stern-Volmer quenching constant of $1.56 \times 10^{5} \mathrm{M}^{-1}$.

\section{Experimental part}

\subsection{Materials and measurements}

All chemical reagents were commercially available and used as received unless otherwise stated. Affinity-purified peanut agglutinin (PNA), concanavalin A (Con A), and aqueous HEPES (2-[4-(2hydroxyethyl)-1-piperazinyl]ethanesulfonic acid) buffer solution were purchased from Sigma-Aldrich Co. and used without further purification. The ${ }^{1} \mathrm{H}$ NMR and ${ }^{13} \mathrm{C}$ NMR spectra were recorded on a Bruker DMX300 NMR spectrometer. The optical rotations were measured with a JASCO DIP-1000 digital polarimeter. Mass spectra were recorded with a VG PLATFORM mass spectrometer using the $\mathrm{ESI}(+)$ technique. The molecular weights of the polymers were determined by an Agilent 1100 GPC system in THF. The number- 
average and weight-average molecular weights $\left(M_{\mathrm{n}}\right.$ and $\left.M_{\mathrm{w}}\right)$ were estimated by using a calibration curve of polystyrene standard (Sigma-Aldrich Co.). IR spectra were recorded using a Perkin-Elmer Paragon 1000 FT-IR spectrometer. Ultraviolet-visible (UV-vis) spectra were measured using a Perkin-Elmer Lamda 900 UV-visNIR spectrophotometer and quartz cells with $1 \mathrm{~cm}$ path length. The fluorescence spectra were measured in a $1 \mathrm{~cm}$ path length using a Perkin-Elmer LS55 luminescence spectrometer.

\subsection{Synthesis of $N, N^{\prime}$-di(4-iodophenyl) 4-propargyloxymethyl aniline (2)}

To a solution of triphenylamine derivative 1 (525 $\mathrm{mg}, 1.0 \mathrm{mmol})$ in THF-CH 3 OH $(1: 1,10 \mathrm{~mL})$ was added $\mathrm{NaBH}_{4}(190 \mathrm{mg}, 5.0 \mathrm{mmol})$. After stirring overnight at room temperature, the resulting mixture was concentrated under reduced pressure, and then the residue was dissolved in EtOAc $(50 \mathrm{~mL})$, washed with water $(50 \mathrm{~mL})$. The organic phase was separated, dried over anhydrous $\mathrm{Na}_{2} \mathrm{SO}_{4}$ and concentrated under reduced pressure to furnish the alcohol intermediate. Without further purification, crude alcohol was dissolved in anhydrous DMF ( $5 \mathrm{~mL}$ ) and then $\mathrm{NaH}(70 \%, 70 \mathrm{mg}, 2.0 \mathrm{mmol})$ was added portionwise at $0{ }^{\circ} \mathrm{C}$. After $30 \mathrm{~min}$, propargyl bromide $(0.11 \mathrm{~mL}, 1.2 \mathrm{mmol})$ was added dropwise under the same reaction condition. The mixture was kept stirring for $2 \mathrm{~h}$ at room temperature, then poured into ice-water $(50 \mathrm{~mL})$, and extracted with EtOAc $(2 \times 100 \mathrm{~mL})$. The combined organic layer was dried over anhydrous $\mathrm{Na}_{2} \mathrm{SO}_{4}$ and concentrated. Purification of the residue on column chromatography (petroleum ether-EtOAc, 6:1) afforded 2 (514 mg, 91\%) as a yellow syrup. ${ }^{1} \mathrm{H}$ NMR $\left(300 \mathrm{MHz}, \mathrm{CDCl}_{3}, \delta\right): 7.44$ $(\mathrm{d}, J=9.0 \mathrm{~Hz}, 4 \mathrm{H}), 7.18(\mathrm{~d}, J=8.4 \mathrm{~Hz}, 2 \mathrm{H}), 6.96(\mathrm{~d}, J=8.4 \mathrm{~Hz}, 2 \mathrm{H})$, $6.73(\mathrm{~d}, J=8.7 \mathrm{~Hz}, 4 \mathrm{H}), 4.48(\mathrm{~s}, 2 \mathrm{H}), 4.13(\mathrm{~d}, J=2.4 \mathrm{~Hz}, 2 \mathrm{H}), 2.40$ (s, $1 \mathrm{H}) .{ }^{13} \mathrm{C}$ NMR $\left(75 \mathrm{MHz}, \mathrm{CDCl}_{3}, \delta\right): 145.9,145.4,137.2,131.7,128.5$, 124.7, 123.5, 84.9, 78.6, 73.8, 70.1, 56.3. IR (KBr): 3290, 2850, 2130, 1610, 1573, 1509, 1485, 1313, 1282, 1079, 1002, $816 \mathrm{~cm}^{-1}$. ESI(+)-MS: calcd for $\mathrm{C}_{22} \mathrm{H}_{17} \mathrm{l}_{2} \mathrm{NO}$ : $565.2[\mathrm{M}]$; found $566[\mathrm{M}+1]^{+}$.

\subsection{Synthesis of monomer 4}

To a mixture of 2 (565 mg, $1.0 \mathrm{mmol})$ and 3 (373 $\mathrm{mg}, 1.0 \mathrm{mmol})$ in $\mathrm{H}_{2} \mathrm{O}$-THF $(1: 1,15 \mathrm{~mL})$ were added freshly prepared aqueous sodium ascorbate $(1.0 \mathrm{M}, 150 \mu \mathrm{L}, 0.15 \mathrm{mmol})$ and $\mathrm{CuSO}_{4}(12 \mathrm{mg}$, $0.075 \mathrm{mmol}$ ). The heterogeneous mixture was stirred vigorously in dark room at $50-60^{\circ} \mathrm{C}$ until complete consumption of the reactants based on TLC analysis. After removal of THF under reduced pressure, water $(20 \mathrm{~mL})$ was added and the product was extracted with EtOAc $(3 \times 25 \mathrm{~mL})$. The combined organic layer was dried over anhydrous $\mathrm{Na}_{2} \mathrm{SO}_{4}$ and evaporated in vacuo. The crude product was subjected to column chromatography (EtOAc-petroleum ether, 1:2) to give 4 as a foamy solid (930 mg, 98\%). $[\alpha]_{\mathrm{D}}^{25}-45^{\circ}\left(\mathrm{c} 1, \mathrm{CHCl}_{3}\right) ;{ }^{1} \mathrm{H}$ NMR (300 MHz, $\left.\mathrm{CDCl}_{3}, \delta\right): 7.87(\mathrm{~s}, 1 \mathrm{H}), 7.50(\mathrm{~d}, J=8.7 \mathrm{~Hz}, 4 \mathrm{H}), 7.26$ (d, $J=8.4 \mathrm{~Hz}, 2 \mathrm{H}), 7.02(\mathrm{~d}, J=8.4 \mathrm{~Hz}, 2 \mathrm{H}), 6.80(\mathrm{~d}, J=8.7 \mathrm{~Hz}, 4 \mathrm{H})$, $5.85(\mathrm{~d}, J=9.3 \mathrm{~Hz}, 1 \mathrm{H}), 5.58-5.51(\mathrm{~m}, 2 \mathrm{H}), 5.25$ (dd, $J=10.2,3.3 \mathrm{~Hz}$, $1 \mathrm{H}), 4.70(\mathrm{~s}, 2 \mathrm{H}), 4.52(\mathrm{~s}, 2 \mathrm{H}), 4.22(\mathrm{~d}, J=6.0 \mathrm{~Hz}, 1 \mathrm{H}), 4.13-4.18(\mathrm{~m}$, 2H), $2.21(\mathrm{~s}, 3 \mathrm{H}), 2.03(\mathrm{~s}, 3 \mathrm{H}), 2.00(\mathrm{~s}, 3 \mathrm{H}), 1.90(\mathrm{~s}, 3 \mathrm{H}) .{ }^{13} \mathrm{C}$ NMR $\left(75 \mathrm{MHz}, \mathrm{CDCl}_{3}, \delta\right): 170.3,169.9,169.7,169.1,147.0,146.4,145.8$, 138.3, 133.2, 129.5, 125.8, 124.6, 121.0, 86.3, 85.9, 74.1, 72.0, 70.8, $68.0,66.9,63.5,61.2,60.4,21.0,20.6,20.5,20.3$. IR (KBr): 2955, $2860,1760,1589,1498,1485,1378,1210,1094,810 \mathrm{~cm}^{-1}$. ESI(+)MS: calcd for $\mathrm{C}_{36} \mathrm{H}_{36} \mathrm{I}_{2} \mathrm{~N}_{4} \mathrm{O}_{10}$ : $938.2[\mathrm{M}]$; found $939[\mathrm{M}+1]^{+}$.

\subsection{General procedure for Suzuki coupling polymerization}

Under a nitrogen atmosphere, sugar-carrying monomer 4 (0.31 $\mathrm{mmol})$, diborate $(0.36 \mathrm{mmol}), \mathrm{Pd}\left(\mathrm{PPh}_{3}\right)_{4}(80 \mathrm{mg})$, and potassium carbonate $(0.5 \mathrm{~g}, 3.62 \mathrm{mmol})$ were placed in a $50 \mathrm{~mL}$ round- bottom flask, and then THF $(20 \mathrm{~mL})$ was added. The mixture was stirred at $70^{\circ} \mathrm{C}$ for $48 \mathrm{~h}$ under a nitrogen atmosphere. The resulting polymers were purified by precipitation in methanol and washed with methanol-acetone in a Soxhlet apparatus for $48 \mathrm{~h}$.

P-3 was obtained as a gray powder with a yield of $78 \% .{ }^{1} \mathrm{H}$ NMR (300 MHz, $\mathrm{CDCl}_{3}, \delta$ ): 8.36-8.25 (m, 2H), 7.90 (br s, $\left.1 \mathrm{H}\right), 7.72-7.59$ (m, 6H), 7.47-7.45 (m, 4H), 7.40-7.10 (m, 6H), 5.87-5.83 (m, 1H), 5.54 (br s, 2H), 5.26-5.23 (m, 1H), 4.74 (br s, 2H), 4.57 (br s, 2H), 4.40-4.36 (m, 2H), 4.19-4.15 (m, 3H), 2.21 (br s, 3H), 2.00 (br s, 6H), 1.90 (br s, 3H), 1.47-1.43 (m, 3H). IR (KBr): 2960, 2863, 1758, 1595 , 1499, 1483, 1380, 1232, 1105, 1046, $809 \mathrm{~cm}^{-1}$. GPC (THF, polystyrene standard): $M_{\mathrm{n}}=21500 \mathrm{~g} / \mathrm{mol}$; polydispersity $=1.75$.

P-4 was obtained as a yellow powder with a yield of $75 \% .{ }^{1} \mathrm{H}$ $\operatorname{NMR}\left(300 \mathrm{MHz}, \mathrm{CDCl}_{3}, \delta\right): 7.82(\mathrm{~s}, 1 \mathrm{H}), 7.69-7.67$ (m, 2H), 7.62-7.60 $(\mathrm{m}, 1 \mathrm{H}), 7.55-7.49(\mathrm{~m}, 6 \mathrm{H}), 7.43-7.38(\mathrm{~m}, 2 \mathrm{H}), 7.29-7.23(\mathrm{~m}, 2 \mathrm{H})$, 7.16-7.12 (m, 2H), 7.09-7.05 (m, 2H), 7.00-6.95 (m, 1H), $5.79(\mathrm{~d}, 1 \mathrm{H})$, $5.50(\mathrm{~m}, 2 \mathrm{H}), 5.18(\mathrm{~d}, 1 \mathrm{H}), 4.66(\mathrm{~s}, 2 \mathrm{H}), 4.48(\mathrm{~s}, 2 \mathrm{H}), 4.17-4.08(\mathrm{~m}$, $3 \mathrm{H}), 2.15$ (s, 3H), 1.98-1.94 (m, 10H), 1.84 (s, 3H), 1.0 (br s, 12H), 0.69-0.66 (m, 10H). IR (KBr): 2930, 2856, 1758, 1603, 1514, 1476, $1372,1321,1224,1098,1046,920,824 \mathrm{~cm}^{-1}$. GPC (THF, polystyrene standard): $M_{\mathrm{n}}=25300 \mathrm{~g} / \mathrm{mol}$; polydispersity $=1.85$.

\subsection{General procedure for deacetylation}

A protected glycopolymer $(0.2 \mathrm{~g})$ was added to a solution of dry $\mathrm{CH}_{2} \mathrm{Cl}_{2}(5 \mathrm{~mL})$ and $\mathrm{CH}_{3} \mathrm{OH}(10 \mathrm{~mL})$ under a nitrogen atmosphere and followed by $\mathrm{CH}_{3} \mathrm{ONa} / \mathrm{CH}_{3} \mathrm{OH}$ solution $(1.0 \mathrm{M}, 0.25 \mathrm{~mL})$. The reaction mixture was stirred overnight at room temperature. After removal of the solvent under reduced pressure, $10 \mathrm{~mL}$ of water was added to the residue. The resulting solution was put in a cellulose dialysis tube (cutoff 3500), dialyzed against water for $2 \mathrm{~d}$, and lyophilized to give the desired solid.

P-1 was obtained in a yield of $94 \% .{ }^{1} \mathrm{H}$ NMR $\left(300 \mathrm{MHz}\right.$, DMSO- $d_{6}$, )): 8.61-8.50 (m, 2H), 8.30-8.28 (m, 1H), 7.78-7.59 (m, 6H), 7.43$7.30(\mathrm{~m}, 4 \mathrm{H}), 7.19-7.08(\mathrm{~m}, 4 \mathrm{H}), 5.49-5.47(\mathrm{~m}, 1 \mathrm{H}), 4.62-4.48(\mathrm{~m}$, $5 \mathrm{H}), 4.05-4.02(\mathrm{~m}, 1 \mathrm{H}), 3.76-3.71(\mathrm{~m}, 2 \mathrm{H}), 3.55-3.50(\mathrm{~m}, 2 \mathrm{H}), 2.12-$ 2.03 (m, 4H), 1.35-1.30 (m, 3H). IR (KBr): 3427, 2945, 2863, 1595, $1514,1475,1321,1232,1105,809 \mathrm{~cm}^{-1}$.

P-2 was obtained in a yield of 95\%. ${ }^{1} \mathrm{H}$ NMR (300 MHz, DMSO- $d_{6}$, o): 8.30 (br s, 2H), 7.90-7.75 (m, 7H), 7.37-7.33 (m, 4H), 7.16-7.06 (m, 6H), 5.35-5.34 (m, 1H), 5.30-5.15 (m, 1H), 4.73-4.55 (m, 4H), 4.10-4.05 (m, 1H), 3.78-3.72 (m, 2H), 3.58-3.50 (m, 2H), 2.12-2.03 $(\mathrm{m}, 4 \mathrm{H}), 1.00-0.86(\mathrm{~m}, 12 \mathrm{H}), 0.69-0.59(\mathrm{~m}, 10 \mathrm{H})$. IR (KBr): 3427 , 2930, 2856, 1603, 1514, 1461, 1328, 1276, 1105, $816 \mathrm{~cm}^{-1}$.

\subsection{Interaction with lectins}

A solution of glycopolymer P-2 was prepared in $10 \mathrm{mM}$ HEPES buffer/DMF (8/2, v/v, pH 7.3) containing $0.1 \mathrm{mM} \mathrm{CaCl}_{2}$ and $0.1 \mathrm{mM}$ $\mathrm{MnCl}_{2}$. Aliquots of the lectin in the same buffer were added to the solution. The final concentration of glycopolymer P-2 is $1.0 \mu \mathrm{M}$, corresponding to the repeating monomer unit. After each addition, the sample was allowed to equilibrate for $1 \mathrm{~h}$ prior to recording a spectrum. Additions of the lectin were continued until no change in the fluorescence intensity was observed. The excitation wavelength was $378 \mathrm{~nm}$ and the emission scan ranged from $380 \mathrm{~nm}$ to $650 \mathrm{~nm}$.

\section{Results and discussion}

\subsection{Synthesis and characterization}

The synthetic route of the monomers and copolymers is outlined in Scheme 1. Functionalized triphenylamine derivative $\mathbf{1}$ was prepared according to a reported method [24]. After reduction with $\mathrm{NaBH}_{4}$, propargyl-attached ether 2 was obtained in a high yield 
(92\% in two steps) followed by reaction with propargyl bromide under a basic condition. The $\mathrm{Cu}(\mathrm{I})$-catalyzed "Click" ligation $[25,26]$ between 2 and peracetylated $\beta$-D-galactopyranosyl azide 3 [27] afforded the key monomer 4 smoothly in $98 \%$ yield. Formation of triazole ring is confirmed by chemical shift at $7.81 \mathrm{ppm}$ (single peak) on ${ }^{1} \mathrm{H}$ NMR spectrum and two peaks at $121.0 \mathrm{ppm}, 145.8 \mathrm{ppm}$ on ${ }^{13} \mathrm{C}$ NMR spectrum. A palladium-catalyzed Suzuki coupling polymerization of the galactose-bearing monomer 4 with corresponding diboronate $(\mathbf{5}, \mathbf{6})$ [28] furnished two well-defined copolymers, poly(fluorene-alt-triphenylamine) and poly(N-ethylcarbazole-alt-triphenylamine) bearing peracetylated galactose residues (P-3, P-4) respectively. Fig. 1 shows ${ }^{1} \mathrm{H}$ NMR spectra of monomer 4, polymers $\mathbf{P}-\mathbf{3}$, and $\mathbf{P}-\mathbf{4}$ in $\mathrm{CDCl}_{3}$ solution. These results clearly indicate that polymerization of carbohydrate-bearing monomers is a good approach to prepare well-defined fluorescent conjugated glycopolymers. After global deacetylation of polymer P-3 or P-4 under Zemplén condition in $\mathrm{CH}_{3} \mathrm{ONa} / \mathrm{CH}_{3} \mathrm{OH}$, the desired glycopolymers (P-1 and P-2) were obtained in an excellent yield and were further characterized by ${ }^{1} \mathrm{H}$ NMR as shown in Fig. 2.
The successful polymerization and deacetylation are also confirmed by FT-IR spectra of the monomers and glycopolymers as shown in Fig. 3. Compared with monomer 4, the absorption bands at $2850-2950 \mathrm{~cm}^{-1}$ on the FT-IR spectra of polymers P-3 and P-4 indicate the $\mathrm{C}-\mathrm{H}$ stretching of alkyl chains derived from diboronate monomers $(5,6)$. After deacetylation, the bands at $1750 \mathrm{~cm}^{-1}$ $(\mathrm{C}=\mathrm{O})$ and $1200 \mathrm{~cm}^{-1}$ (C-O stretching in ester) of $\mathbf{P}-\mathbf{3}$ and $\mathbf{P}-\mathbf{4}$ disappeared. In addition, the broad absorption bands at $3400 \mathrm{~cm}^{-1}$ on the FT-IR spectra of polymers P-1 and P-2 show O-H stretching from the free hydroxyl groups on sugar moieties.

Gel-permeation chromatography (GPC) analysis with polystyrene standards shows number-averaged molecular weights $\left(M_{\mathrm{n}} \mathrm{S}\right)$ of 21500 and $25300 \mathrm{~g} / \mathrm{mol}$ for P-3 and P-4 with polydispersities of 1.75 and 1.85 , respectively. Both $\mathbf{P}-\mathbf{3}$ and $\mathbf{P}-\mathbf{4}$ are readily soluble in common solvents such as methylene chloride, chloroform, and THF, but insoluble in methanol, ethanol, acetone, and water. The solubility of the deacetylated polymers is different from their precursors. Neither P-1 nor P-2 is soluble in water or HEPES buffer solution. However, they show solubility in DMF,<smiles>C#CCOCc1ccc(N(c2ccc(I)cc2)c2ccc(I)cc2)cc1</smiles>

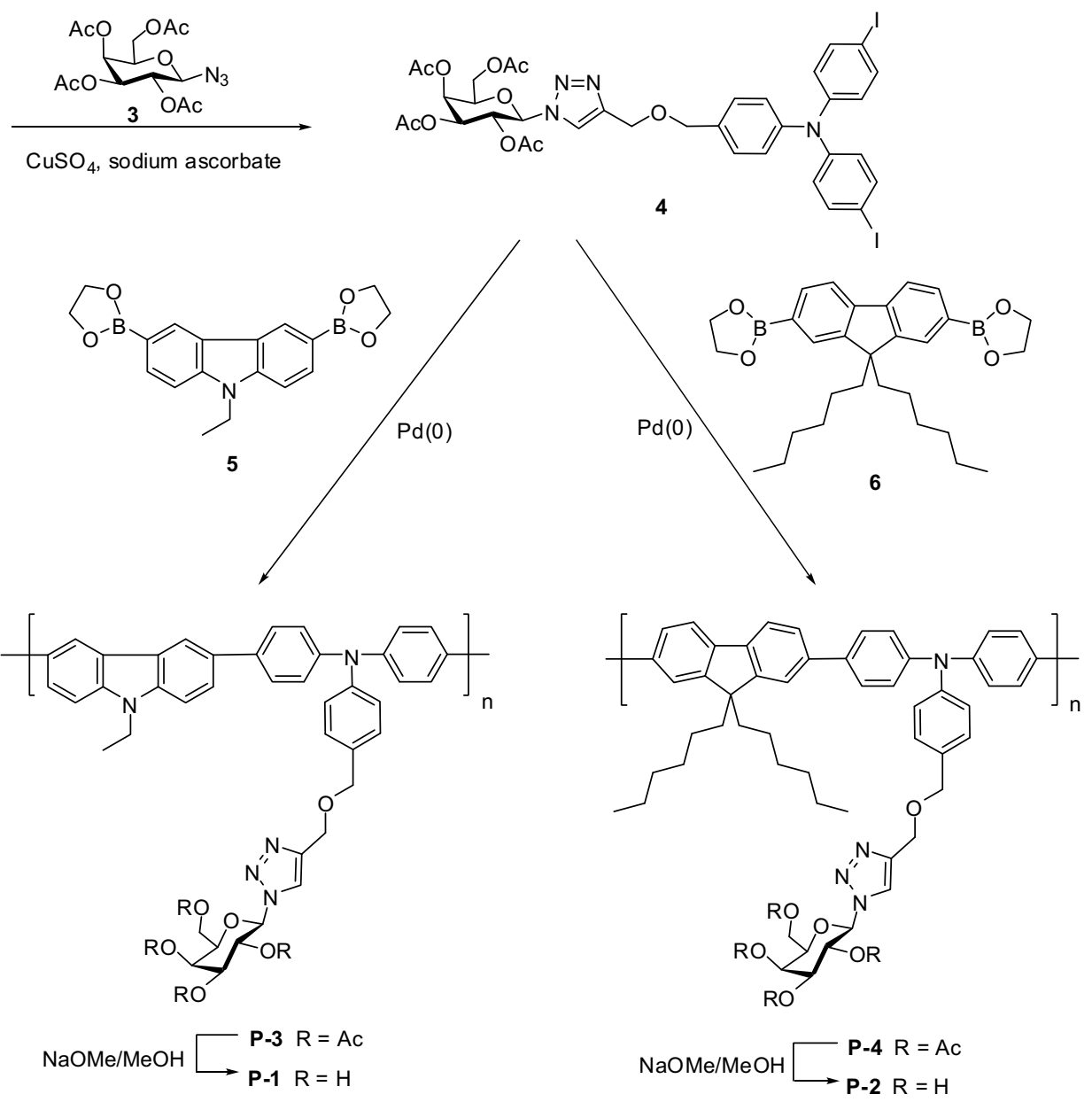

Scheme 1. Preparation of the monomers and copolymers. 


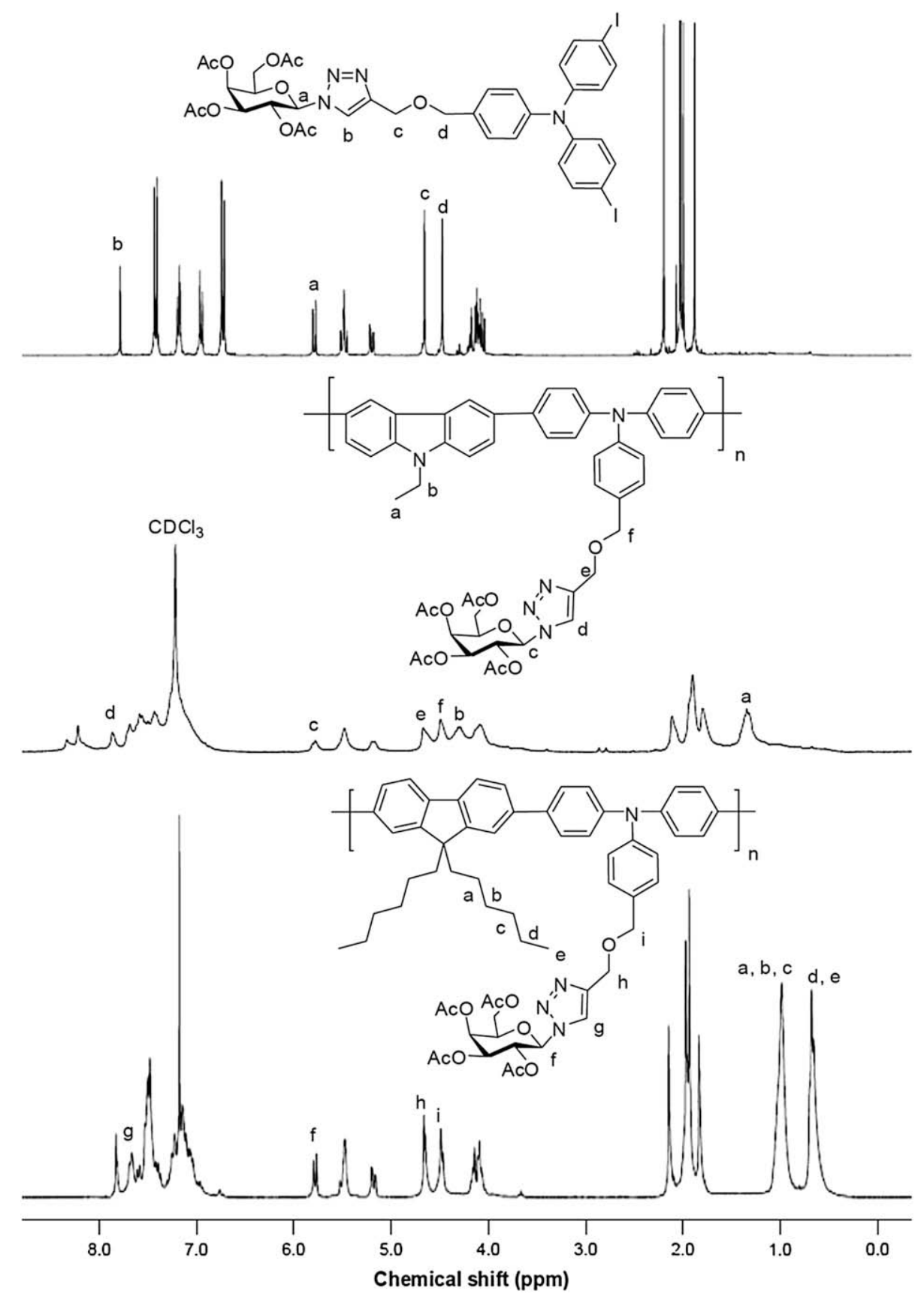

Fig. 1. ${ }^{1} \mathrm{H}$ NMR spectra of monomer $\mathbf{4}$, copolymers $\mathbf{P}-\mathbf{3}$ and $\mathbf{P}-\mathbf{4}$ in $\mathrm{CDCl}_{3}$ solution.

DMSO and HEPES buffer/DMF (8/2, v/v) as well. Similar results were reported by Takasu and coworkers [18] for sugar-carrying poly (phenylene-vinylene).

\subsection{Optical properties}

The precursor polymer P-3 exhibits an absorption maximum peak at $336 \mathrm{~nm}$ and an emission maximum peak at $414 \mathrm{~nm}$ in THF solution, which are assigned to the $\pi-\pi^{*}$ transition of the conjugated polymer backbone (Fig. 4a). Compared with P-3, red shifts in absorption and emission are observed for polymer P-4 that shows an absorption maximum peak at $368 \mathrm{~nm}$ and an emission maximum peak at $434 \mathrm{~nm}$ in THF solution. The red shifts are ascribed to the enhanced extent of $\pi$ orbital overlap and electron-donating effect due to the dihexylfluorene residues in the backbone of polymer P-4.

As for the resulting glycopolymers in DMSO solution, polymer P-1 exhibits an absorption maximum peak at $338 \mathrm{~nm}$ and an emission maximum peak at $432 \mathrm{~nm}$, while polymer $\mathbf{P - 2}$ displays an absorption maximum peak at $373 \mathrm{~nm}$ and an emission maximum peak at $454 \mathrm{~nm}$ (Fig. 4b). Compared with their precursor polymers, the red shifts in both absorption and emission spectra for polymers P-1 and P-2 with increased polarity could be due to enhanced planar conformation or aggregation of polymer main chain in the polar solvent [12]. Fluorescence quantum yields of the polymers were measured in dilute DMSO solution, and calculated by using quinine sulfate in $0.1 \mathrm{M}$ sulfuric acid as the reference absolute quantum efficiency (55\%) [29]. Polymer P-2 possesses good 


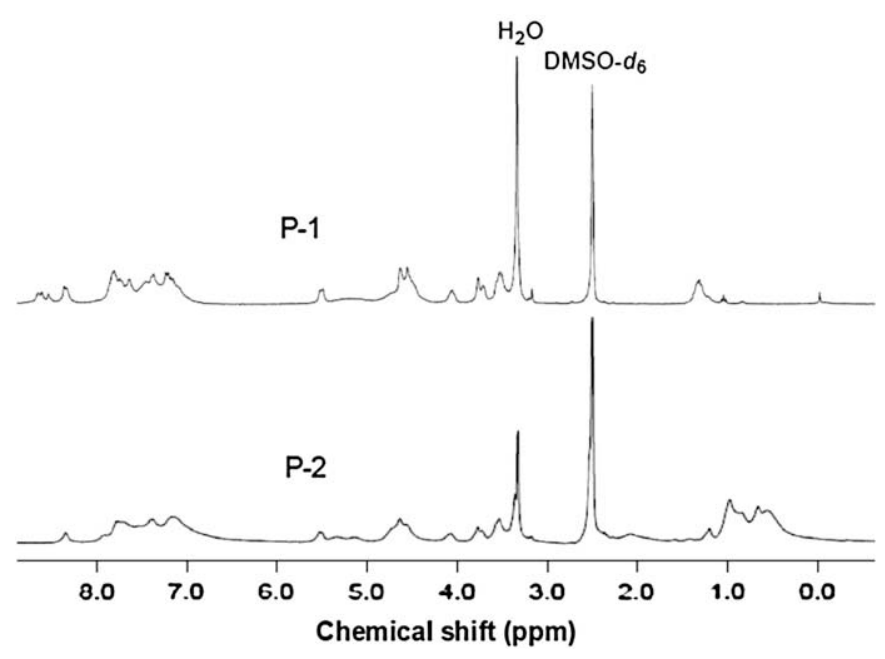

Fig. 2. ${ }^{1} \mathrm{H}$ NMR spectra of glycopolymers $\mathbf{P}-\mathbf{1}$ and $\mathbf{P - 2}$ in DMSO- $d_{6}$ solution.

fluorescence quantum yield (61\%), however, polymer P-1 shows a lower fluorescence quantum yield (13\%) probably arising from self-aggregation.

\subsection{Response to lectins}

The affinities of the glycopolymers are selective to specific lectins. It is known that concanavalin A (Con A), which is a tetramer with four carbohydrate-binding sites, specifically binds to Dmannose and D-glucose residues, whereas peanut agglutinin (PNA) is a galactose-binding lectin from Arachis hypogaea. We selected glycopolymer P-2 to investigate specific interactions with lectins. A solution of P-2 in HEPES buffer/DMF $(8 / 2, v / v)$ was exposed to Con $A$, no distinct change in its fluorescent properties was observed. While, when PNA was used, efficient concentration-dependent fluorescence quenching occurred at low concentrations of the lectin (Fig. 5). There are broadly two mechanisms for quenching processes in nature. One is static, another is dynamic [30]. Conjugated polymers without organometallic fragments feature short emissive lifetimes (0.2-0.5 ns) that make dynamic quenching of polymers difficult, therefore, static quenching is predominant [31,32]. In static quenching, the quencher forms a ground state complex with the fluorophore, and a linear Stern-Volmer relationship occurs:

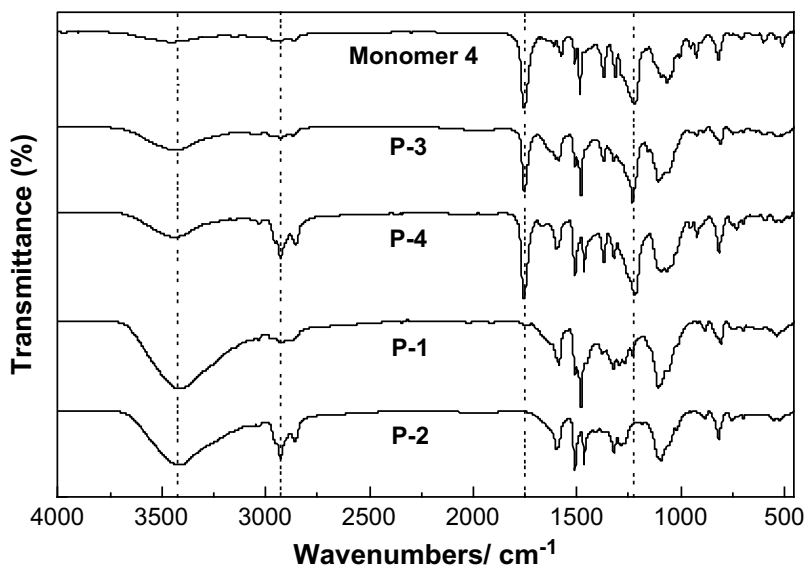

Fig. 3. FT-IR spectra of monermer 4 and copolymers P-1, P-2, P-3 and P-4.
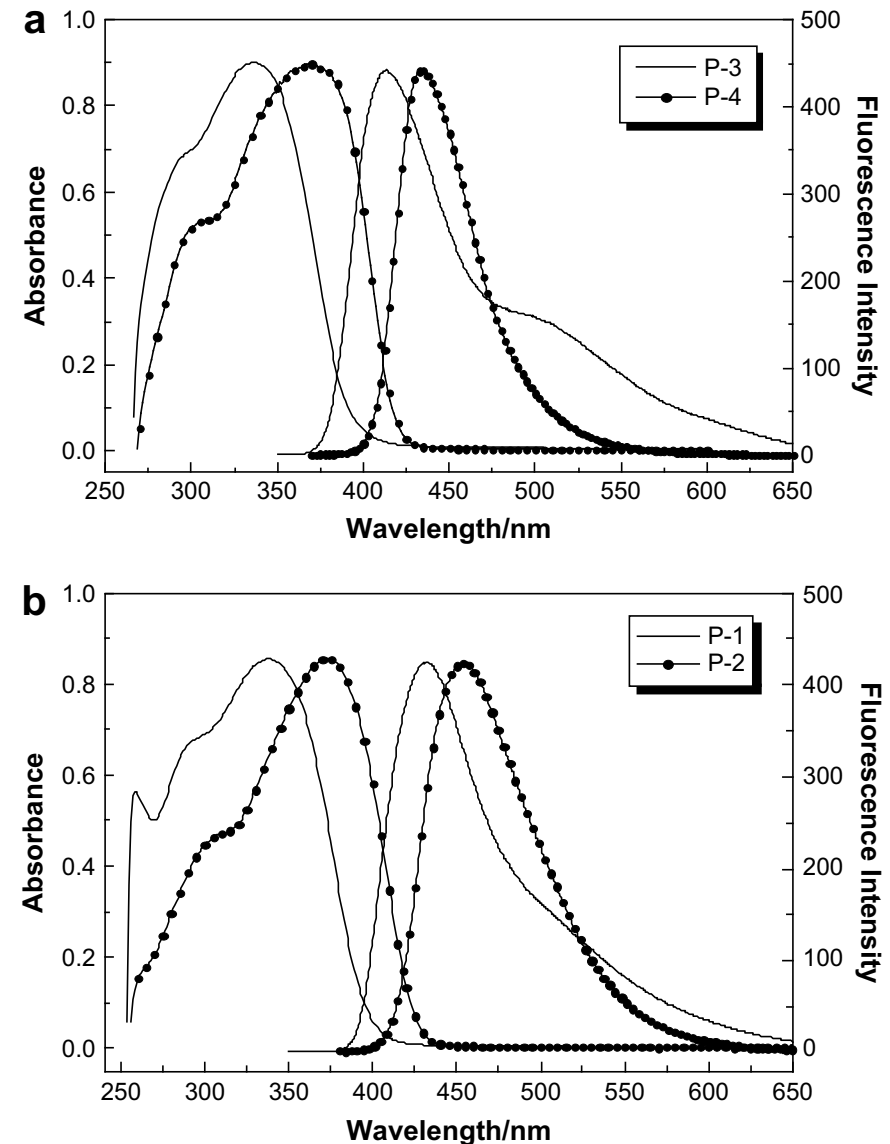

Fig. 4. UV-vis absorption and fluorescence spectra of polymers P-3, P-4 (a) in THF solution and polymers P-1, P-2 (b) in DMSO solution.

$I_{0} / I=1+K_{\mathrm{SV}}[\mathrm{Q}]$

where $I_{0}$ is the fluorescent intensity in the absence of quencher, $I$ is the fluorescent intensity as a function of quencher concentration [Q], and $K_{\mathrm{SV}}$ is the Stern-Volmer constant, defining the efficiency of quenching $[11,19,30]$. The Stern-Volmer quenching constant of polymer P-2 by PNA was calculated as $1.56 \times 10^{5} \mathrm{M}^{-1}$ based on the linear part of the curve (Fig. 5). When all other variables are kept

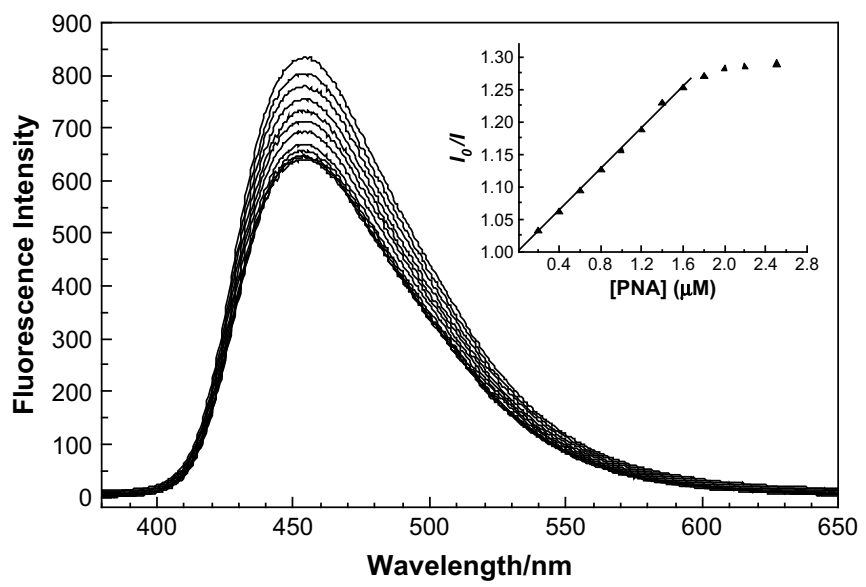

Fig. 5. Fluorescence spectra and Stern-Volmer plot (inset) of glycopolymer P-2 in the absence and presence of different concentrations of PNA in HEPES buffer/DMF $(8 / 2$ $\mathrm{v} / \mathrm{v}$ ) solution: PNA concentrations $(\mu \mathrm{M})$ from the top downwards are $0,0.2,0.4,0.6,0.8$, $1,1.2,1.4,1.6,1.8,2.0,2.2$, and 2.5 . 
constant, the higher $K_{\mathrm{SV}}$ means the lower concentration of quencher is required to quench the fluorescence $[11,19,30]$. These results revealed that PNA can selectively bind to polymer P-2 based on multivalent interactions.

\section{Conclusion}

In this article, two well-defined triphenylamine-based fluorescent conjugated glycopolymers were synthesized and characterized. With fluorescent scaffolding backbones and reporting carbohydrate ligands, the glycopolymers can be as novel multivalent model systems for carbohydrate-protein interaction studies and biosensor applications. The studies of carbohydrate-lectin interactions were performed by titration of peanut agglutinin (PNA) to D-galactose-bearing poly(fluorene-alt-triphenylamine) copolymer P-2 resulting in a significant fluorescence quenching of the polymer with a Stern-Volmer quenching constant of $1.56 \times 10^{5} \mathrm{M}^{-1}$. Possible mechanism for the fluorescence quenching of P-2 is attributed to its aggregation derived from carbohydratelectin interactions, resulting in self-quenching. These results revealed that triphenylamine-based fluorescent conjugated polymers with pendant sugars had potential application in detecting biological stimuli.

\section{Acknowledgements}

The financial supports of the Ministry of Science and Technology of China (National Basic Research Program, grant no. 2007CB808000) and National Science Foundation of China (grant no. 20672025) are acknowledged.

\section{References}

[1] Lis H, Sharon N. Chem Rev 1998;98:637-74.

[2] Mammen M, Choi SK, Whitesides GM. Angew Chem Int Ed 1998;37:2755-94

[3] Jelinek R, Kolusheva S. Chem Rev 2004;104:5987-6015.

[4] Kiessling LL, Gestwicki JE, Strong LE. Curr Opin Chem Biol 2000;4:696-703.

[5] Lundquist JJ, Toone EJ. Chem Rev 2002;102:555-78.

[6] Miyata T, Nakame K. Trends Polym Sci 1997;5:198-206.

[7] Okada M. Prog Polym Sci 2001;26:67-104.

[8] Wang Q, Dordick JS, Linhardt RJ. Chem Mater 2002;14:3232-44.

[9] Charych DH, Nagy JO, Spevak W, Bednarski MD. Science 1993;261:585-8.

[10] Baek MG, Stevens R, Charych DH. Bioconjugate Chem 2000;11:777-88.

[11] Xue C, Luo FT, Liu H. Macromolecules 2007;40:6863-70.

[12] Xue C, Donuru VR, Liu H. Macromolecules 2006;39:5747-52.

[13] Erdogan B, Wilson JN, Bunz UHF. Macromolecules 2002;35:7863-4.

[14] Disney MD, Zheng J, Swager TM, Seeberger PH. J Am Chem Soc 2004; $126: 13343-6$

[15] Kim I-B, Erdogan B, Wilson JN, Bunz UHF. Chem Eur J 2004;10:6247-54.

[16] Kim I-B, Wilson JN, Bunz UHF. Chem Commun 2005:1273-5.

[17] Phillips RL, Kim I-B, Carson BE, Tidbeck B, Bai Y, Lowary TL, et al. Macromolecules 2008;41:7316-20.

[18] Takasu A, Iso K, Dohmae T, Hirabayashi T. Biomacromolecules 2006;7:411-4.

[19] Xue C, Velayudham S, Johnson S, Sha R, Smith A, Brewer W, et al. Chem Eur J 2009;15:2289-95.

[20] Mitschke U, Bäuerle P. J Mater Chem 2000;10:1471-507.

[21] Günes S, Neugebauer H, Sariciftci NS. Chem Rev 2007;107:1324-38.

[22] Cremer J, Briehn CA. Chem Mater 2007;19:4155-65.

[23] Feng J, Li Y, Yang M. J Polym Sci Part A Polym Chem 2009;47:222-30.

[24] Ning Z, Chen Z, Zhang Q, Yan Y, Qian S, Cao Y, et al. Adv Funct Mater 2007; $17: 3799-807$.

[25] Kolb HC, Finn MG, Sharpless KB. Angew Chem Int Ed 2001;40:2004-21.

[26] Rostovtsev VV, Green LG, Fokin VV, Sharpless KB. Angew Chem Int Ed 2002;41:2596-9.

[27] Tropper FD, Andersson FO, Braun S, Roy R. Synthesis 1992:618-20.

[28] Li Y, Ding J, Day M, Tao Y, Lu J, D'iorio M. Chem Mater 2004;16:2165-73.

[29] Demasa JN, Crosby GA. J Phys Chem 1971;75:991-1024.

[30] Lakowicz JR. Principles of fluorescence spectroscopy. 3rd ed. New York: Springer; 2006.

[31] Zhou Q Swager TM. J Am Chem Soc 1995;117:12593-602.

[32] Tan CY, Alas E, Muller JG, Pinto MR, Kleiman VD, Schanze KS. J Am Chem Soc 2004;126:13685-94. 